\section{Commentary: It's a long road ahead}

\author{
Pierre-Luc Bernier, MD, CM, MPH, FRCSC
}

Williams-Beuren syndrome is a genetic abnormality caused by the deletion of multiple genes from the region q11.23 of chromosome 7. This impacts on multiple organ systems. Importantly, the gene ELN coding for elastin is deleted, which results in a lack of elastin. This is then associated with connective tissue abnormalities and cardiovascular disease, such as supravalvular aortic stenosis (SVAS) and supravalvular pulmonary stenosis.

Patients with SVAS are often treated surgically during childhood. Various techniques exist, but commonly a patch angioplasty of the aortic root, sinotubular junction and ascending aorta is performed. SVAS can have a variable presentation and evolution. Type I presents as a discrete form and type II often presents as a more diffuse form that also involves the aortic arch. The exact incidence of the discreet and diffuse forms of the disease is unknown. It is important to note that aortic valve pathology may be present in approximately one half of patients with SVAS. Various studies have reported the need for reoperation after surgical repair of SVAS during childhood in a range of $0 \%$ to $32 \%$. The most common indication for late reintervention appears to be the treatment of progressive aortic valve disease.

In the paper "Late Reoperation After Proximal Repair of Supravalvar Stenosis for Diffuse Form of Williams-Beuren Syndrome," Katahira and colleagues ${ }^{2}$ describe the case of a patient presenting at a relatively advanced age with aortic

From the Division of Cardiovascular Surgery, Department of Pediatric Surgery, McGill University, Montreal, Quebec, Canada.

Disclosures: The author reported no conflicts of interest.

The Journal policy requires editors and reviewers to disclose conflicts of interest and to decline handling or reviewing manuscripts for which they may have a conflict of interest. The editors and reviewers of this article have no conflicts of interest.

Received for publication Nov 24, 2019; revisions received Nov 24, 2019; accepted for publication Nov 29, 2019; available ahead of print Feb 20, 2020.

Address for reprints: Pierre-Luc Bernier, MD, CM, MPH, FRCSC, The Montreal Children's Hospital, McGill University Health Center, 1001 Decarie Blvd, Room B.04.2917, Montreal, Quebec H4A 3J1, Canada (E-mail: pierre-luc.bernier@ mcgill.ca).

JTCVS Techniques 2020;3:82

2666-2507

Copyright (c) 2020 The Authors. Published by Elsevier Inc. on behalf of The American Association for Thoracic Surgery. This is an open access article under the CC BY-NCND license (http://creativecommons.org/licenses/by-nc-nd/4.0/).

https://doi.org/10.1016/j.xjtc.2019.11.017

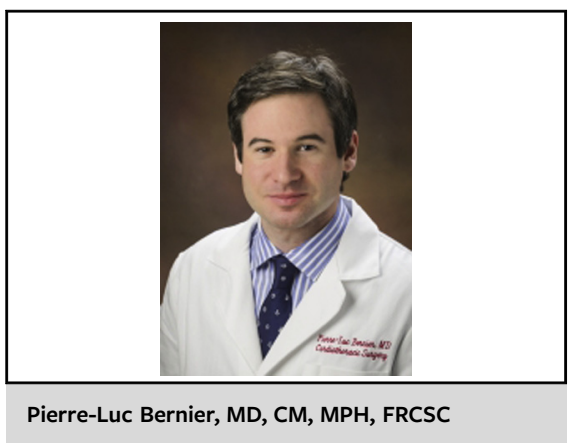

CENTRAL MESSAGE

Pediatric surgical correction of Williams-Beuren syndromeassociated supravalvular aortic stenosis is not a definitive treatment. It is a long road to adulthood, and long-term follow-up is necessary.

valve disease, recurrence of supravalvular aortic stenosis, and proximal arch obstruction. The authors describe their technique for replacement of the diseased aortic valve, the stenotic ascending aorta, and proximal aortic arch. A video summarizing and illustrating the procedure quite effectively is included in the report.

This report demonstrates the complexity of SVAS associated with Williams-Beuren syndrome. We often hope to provide definitive treatments with repair of SVAS in the childhood period. However, reports like this are clear evidence that the natural history of genetic diseases such as Williams-Beuren syndrome is not entirely understood nor predictable. Consequently, the optimal treatment remains unknown. As congenital cardiac surgeons treating our young patients, we often hope for complete cures, but temporary treatments are what we truly offer. Undoubtedly, it's a long road ahead for children with Williams-Beuren syndrome.

\section{References}

1. Deo SV, Burkhart HM, Dearani JA, Schaff HV. Supravalvar aortic stenosis: current surgical approaches and outcomes. Expert Rev Cardiovasc Ther. 2013;11:879-90.

2. Katahira S, Sugimura Y, Lichtenberg A, Akhyari P. Late reoperation after proximal repair of supravalvar stenosis for diffuse form of Williams-Beuren syndrome. J Thorac Cardiovasc Surg Tech. 2020;3:79-81. 